\title{
Origin of Indian Ocean Seamount Province by shallow recycling of continental lithosphere
}

\author{
K. Hoernle ${ }^{1 \star}$, F. Hauff', R. Werner ${ }^{1}$, P. van den Bogaard', A. D. Gibbons ${ }^{2}$, S. Conrad ${ }^{1}$ and R. D. Müller ${ }^{2}$
}

The origin of the Christmas Island Seamount Province in the northeast Indian Ocean is enigmatic. The seamounts do not form the narrow, linear and continuous trail of volcanoes that would be expected if they had formed above a mantle plume $^{1,2}$. Volcanism above a fracture in the lithosphere ${ }^{3}$ is also unlikely, because the fractures trend orthogonally with respect to the east-west trend of the Christmas Island chain. Here we combine ${ }^{40} \mathrm{Ar} /{ }^{39} \mathrm{Ar}$ age, $\mathrm{Sr}, \mathrm{Nd}, \mathrm{Hf}$ and high-precision $\mathrm{Pb}$ isotope analyses of volcanic rocks from the province with plate tectonic reconstructions. We find that the seamounts are 47136 million years old, decrease in age from east to west and are consistently 0-25 million years younger than the underlying oceanic crust, consistent with formation near a mid-ocean ridge. The seamounts also exhibit an enriched geochemical signal, indicating that recycled continental lithosphere was present in their source. Plate tectonic reconstructions show that the seamount province formed at the position where West Burma began separating from Australia and India, forming a new mid-ocean ridge. We propose that the seamounts formed through shallow recycling of delaminated continental lithosphere entrained in mantle that was passively upwelling beneath the mid-ocean ridge. We conclude that shallow recycling of continental lithosphere at mid-ocean ridges could be an important mechanism for the formation of seamount provinces in young ocean basins.

Volcanic seamounts are one of the most abundant features on the ocean floor $\left(>20,000\right.$ at least $\left.1 \mathrm{~km} \mathrm{high}^{4}\right)$, yet the origin of most seamounts remains elusive. The diffuse Christmas Island Seamount Province (CHRISP) extends from the Argo Basin to the Wharton Basin, west of the Investigator Rise, covering $\sim 1,000,000 \mathrm{~km}^{2}$ (Fig. 1). In addition to Christmas Island and the Cocos/Keeling Islands, it consists of $\sim 50$ large, up to $4,500 \mathrm{~m}$ high seamounts, and abundant smaller volcanic structures. During the RV Sonne SO199 CHRISP Expedition, 54 seamounts were partially mapped with the SIMRAD EM 120 multi-beam echo-sounding system and 38 were sampled by dredging. The recovered rocks indicate that all structures are volcanic in origin. Compositions range from tholeiitic to basanitic to trachytic, with alkali basalts being the main parental lava type. The abundant large guyots indicate that this was a former province of ocean island volcanoes, which were eroded to sea level and subsequently subsided $(1,200-3,000 \mathrm{~m})$. The goal of this study was to constrain the origin of the CHRISP and to determine if its source(s) could have affected the chemistry of the Indian upper mantle.

Step-heating plateau ages on plagioclase, hornblende, Kfeldspar, glass and matrix separates were generated from 32 seamount and 10 Christmas Island samples (Supplementary

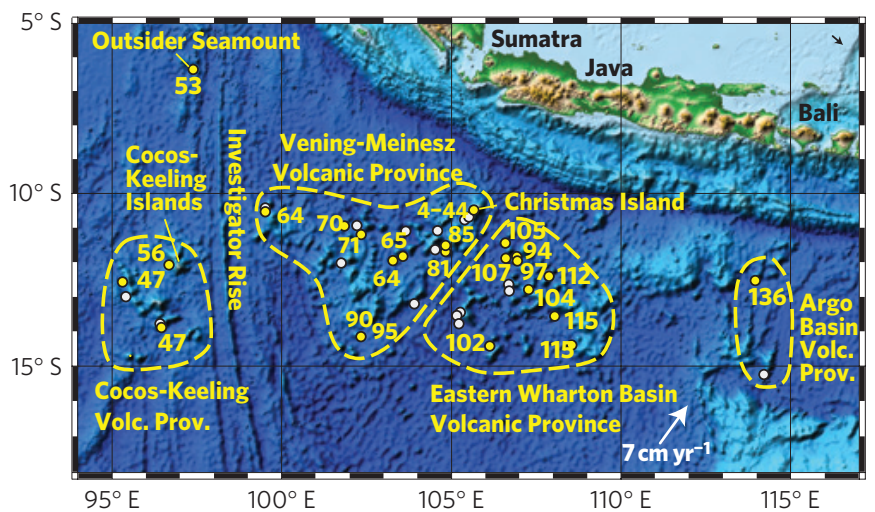

Figure 1 | Bathymetric map ${ }^{31}$ of the Christmas Island Seamount Province (CHRISP) summarizing seafloor morphology and Ar/Ar ages in millions of years. The CHRISP forms a diffuse volcanic belt with an $\mathrm{E}-\mathrm{W}$ length of $\sim 1,800 \mathrm{~km}$ and a N-S width of $\sim 600 \mathrm{~km}$ and is divided into four sub-provinces: (1) Argo Basin (136 Myr), (2) Eastern Wharton Basin (94-115 Myr), (3) Vening-Meinesz (64-95 Myr; Christmas Island 37-44 and $4 \mathrm{Myr}$ ), and (4) the Cocos/Keeling (47-56 Myr) volcanic provinces. Also shown is Outsider Seamount ( $53 \mathrm{Myr}$ ). Plate motion vector and rate from UNAVCO model (http://www.unavco.org).

Information S1). The ages of the seamounts and the underlying crust decrease from east to west: from Argo Basin Province (AP, 136 Myr; underlying crust 154-134 Myr) to Eastern Wharton Basin Province (EWP, 115-94 Myr; crust 120-105 Myr from SE to NW) to Vening-Meinesz Province (VMP, 95-64 Myr; crust $\sim 100-78$ Myr from SE to NW) to Cocos-Keeling Province (CKP, 56-47 Myr; crust 67-61 Myr from S to N; refs 5,6; Fig. 1). A plot of longitude versus age forms a good linear correlation $\left(r^{2}=0.87\right)$. The age difference between a seamount sample and the underlying crust is $0-25 \mathrm{Myr}$, indicating that the seamounts formed on or near the West Burma-Australian/Indian spreading ridge. Christmas Island and its submarine flanks record two younger, intraplate phases of volcanism: (1) the Eocene shield phase (44-37 Myr) and (2) the Pliocene late phase (4.5-4.3 Myr).

The isotopic compositions of the CHRISP display a large range (Supplementary Table S2; Fig. 2) and extend to more enriched compositions than endmember enriched mantle one (EM1)-type hotspot volcanism, such as Pitcairn Island and Walvis Ridge, but overlap with the Afanasy-Nikitin Rise and Seamount, volcanic structures on the sea floor south of India ${ }^{7,8}$. On the uranogenic $\mathrm{Pb}$ isotope diagram, the CHRISP samples overlap the Indian midocean-ridge basalt (MORB) field but extend to higher ${ }^{207} \mathrm{~Pb} /{ }^{204} \mathrm{~Pb}$ 
a

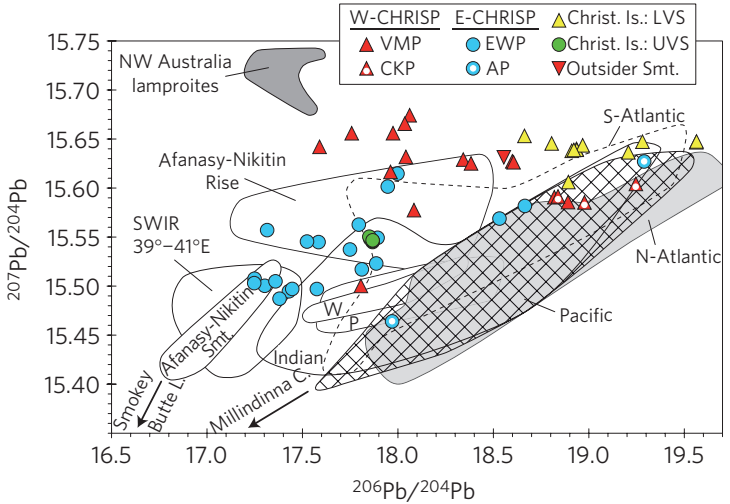

b

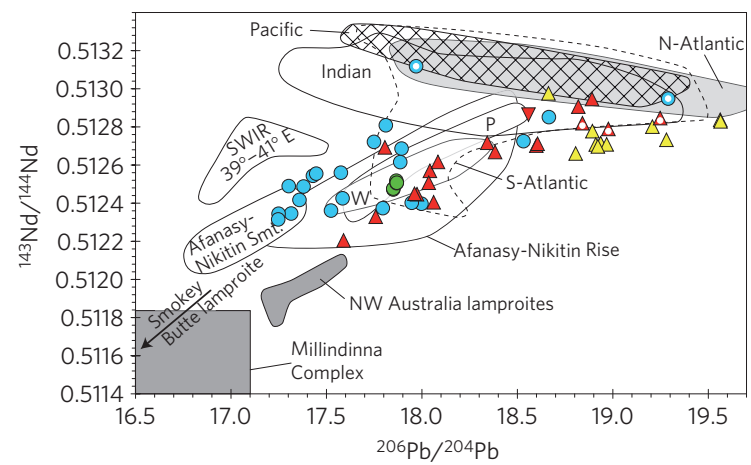

ENd

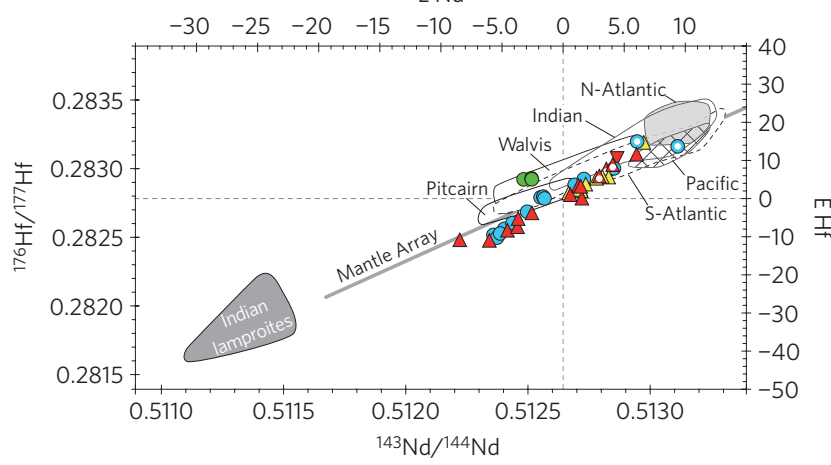

Figure 2 | The CHRISP volcanism displays a large range in isotopic composition. a-c, Isotope diagrams illustrate that mixing of MORB (fields from PetDB: http://www.petdb.org) with NW Australian ${ }^{9}$ and Indian ${ }^{10}$ lamproites and the NW Australian mafic-ultramafic-layered Millindinna Complex ${ }^{11}$ can generate the CHRISP, SWIR $\left(39^{\circ}-41^{\circ} \mathrm{E}\right)$, Walvis Ridge $(W)$, Pitcairn (P) and Afanasy-Nikitin Rise and Seamount (Smt.; refs 8,22,25 (and references therein), 30) compositions. Abbreviations: Argo Basin Province (AP), Eastern Wharton Basin Province (EWP), Vening-Meinesz Province (VMP), Cocos-Keeling Province (CKP), Christmas Island (Christ. Is.), Lower and Upper Volcanic Series (LVS and UVS respectively). Errors (see Supplementary Information S2) are smaller than the symbol size.

at low ${ }^{206} \mathrm{~Pb} /{ }^{204} \mathrm{~Pb}$ isotope ratios than MORB and oceanic intraplate volcanism. The high ${ }^{207} \mathrm{~Pb} /{ }^{204} \mathrm{~Pb}$ requires $\mathrm{U}$ enrichment in the early history of the Earth, owing to the shorter half-life of ${ }^{235} \mathrm{U}$ $(0.7 \mathrm{Gyr})$ than ${ }^{238} \mathrm{U}(4.5 \mathrm{Gyr})$, and then long-term isolation from the convecting mantle. The only known source of such $\mathrm{Pb}$ is Archaean continental lithosphere. Lamproites are small-degree melts derived from enriched (through ancient metasomatism) parts of the subcontinental lithospheric mantle (SCLM). Lamproites from NW Australia ${ }^{9}$ and India ${ }^{10}$ show that SCLM has the appropriate enriched endmember composition to form the CHRISP if mixed with MORB (Fig. 2). The Archaean mafic-ultramafic Millindinna Complex in NW Australia has very low ${ }^{206} \mathrm{~Pb} /{ }^{204} \mathrm{~Pb}(14.7-17.1)$,
${ }^{207} \mathrm{~Pb} /{ }^{204} \mathrm{~Pb}(14.8-15.4)$ and ${ }^{143} \mathrm{Nd} /{ }^{144} \mathrm{Nd}$ (0.5114-7; ref. 11). Mixing of Pacific/N. Atlantic MORB and metasomatized SCLM with compositions similar to lamproites and the Millindinna Complex and/or continental crust can explain the full range of compositions found in the Indian Ocean, including CHRISP, Afanasy-Nikitin and Indian MORB (Fig. 2).

Propagating fault or mantle plume models are generally invoked to explain the origin of age-progressive island/seamount volcanism. As all major faults and fracture zones (for example, Investigator Rise) in the NE Indian Ocean have a $\mathrm{N}-\mathrm{S}$ rather than $\mathrm{E}-\mathrm{W}$ strike (Fig. 1), tectonic structures on the sea floor cannot explain the $\mathrm{E}-\mathrm{W}$ elongation and age progression of the CHRISP. The plume hypotheses also cannot adequately explain the origin of the CHRISP, because (1) there are no known hotspots that could have formed this volcanic chain, (2) the CHRISP is much wider (up to $600 \mathrm{~km}$ ) and discontinous than well-defined, continuous hotspot tracks, for example, the Hawaiian and Louisville island/seamount chains ( $<200 \mathrm{~km}$ wide), (3) $>100 \mathrm{Myr}$ of volcanism occurred within $150 \mathrm{~km}$ of Christmas Island, (4) the beginning of the CHRISP, unlike many hotspots (for example, Tristan/Gough, Réunion and Galápagos), is not associated with a large-scale flood basalt event, and (5) the volcanism in the CHRISP ends at $\sim 50$ Myr. Plate tectonic reconstructions made using GPlates ${ }^{12}$ (Supplementary Information S3) provide further evidence against a plume origin for the CHRISP (Fig. 3). Although a stationary plume located beneath the AP at $136 \mathrm{Myr}$ could also have formed the EWP (115-94 Myr), it could not have generated younger volcanism in the EWP (93-70 Myr), VMP and Christmas Island (95-4 Myr) or CKP (56-47 Myr). Models involving a migrating plume also cannot adequately explain the morphology, width, elongation and age progression of the CHRISP.

The plate tectonic reconstructions, however, place extra constraints on the origin of the CHRISP. They show that the CHRISP formed at the same location where West Burma separated from Australia and Greater India (Fig. 3). Therefore, SCLM and/or lower crust simply needed to be removed from the base of the separating blocks and recycled to form the CHRISP (Fig. 4). Outcrops of the NW Australian lamproites and Millindinna Complex are within $500 \mathrm{~km}$ of the rifted margin (Fig. 3a). Combined seismic tomography, uplift patterns, temporal variations in age and geochemistry of volcanism and numerical modelling provide compelling evidence that continental lithosphere and lower crust are being delaminated at present-day continental rifts, such as the margins of the Basin and Range and the Rio Grande rift systems bordering the Colorado Plateau, western USA (refs 13-15).

Studies of mantle xenoliths have shown that metasomatism, especially prevalent at the base of the lithosphere, increases the garnet and clinopyroxene proportion and thus the density of the SCLM (refs 16,17). Therefore metasomatized areas of even Archaean SCLM, despite its generally low density ${ }^{18}$, can be delaminated into the convecting mantle. Heating of the cold, dense detached SCLM will decrease its density, facilitating the eventual rise of such mantle. In addition, heating and stirring could cause dismemberment of detached mantle, allowing less dense (for example, with less garnet) Archaean SCLM or lower crust to rise. Numerical modelling shows that sublithospheric convection (even in the absence of plate motion) can entrain up to $30 \%$ dense eclogite (for example, subducted ocean crust) with a similar density to metasomatized Archaean SCLM (ref. 18) and bring it from the transition zone to the surface ${ }^{19}$, which is even more likely beneath super-fast Cretaceous mid-ocean ridges ${ }^{20}$. We propose that the CHRISP seamounts formed on or near the W. Burma/Australian MOR through decompression melting of metasomatized, volatile $\left(\mathrm{H}_{2} \mathrm{O}\right.$ and $\left.\mathrm{CO}_{2}\right)$-rich Archaean SCLM (and/or lower crust) and MORB source mantle and/or recycled MORB (Fig. 4b). The GPlates model shows that full spreading rates 
a $150 \mathrm{Myr}$

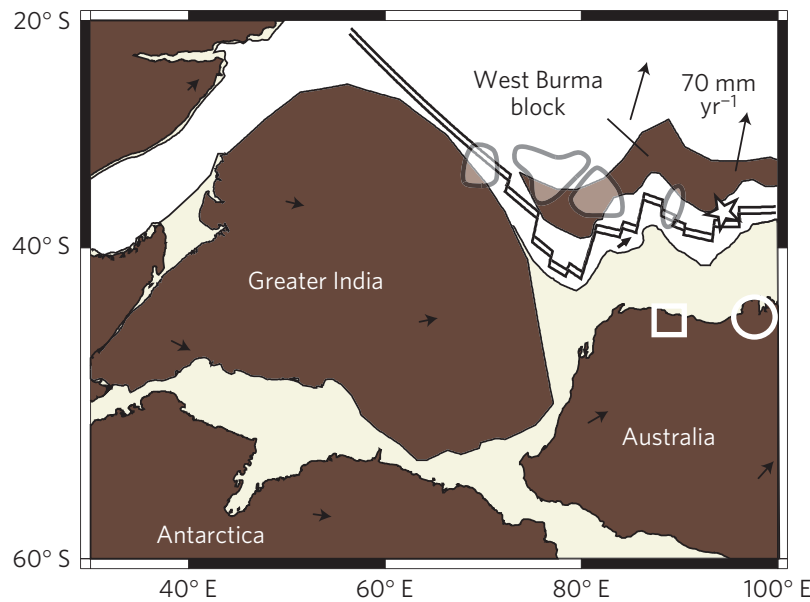

c $80 \mathrm{Myr}$

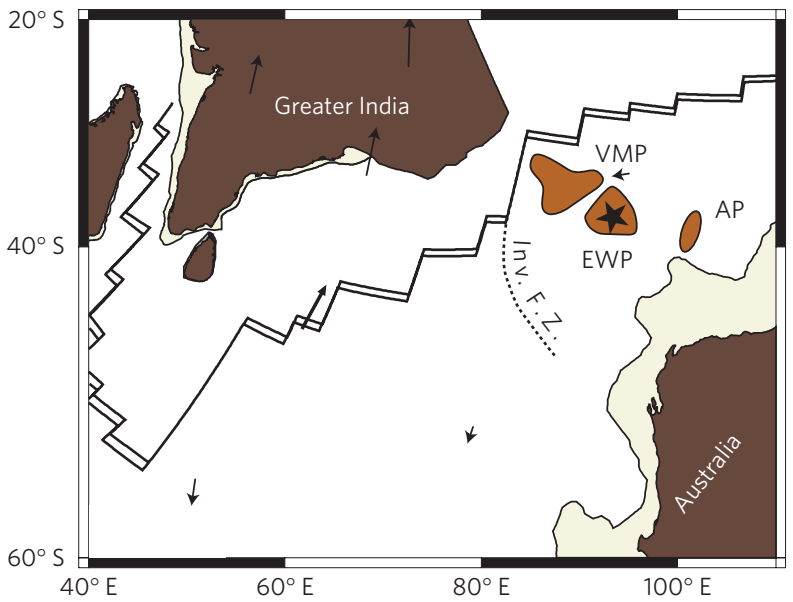

b $110 \mathrm{Myr}$

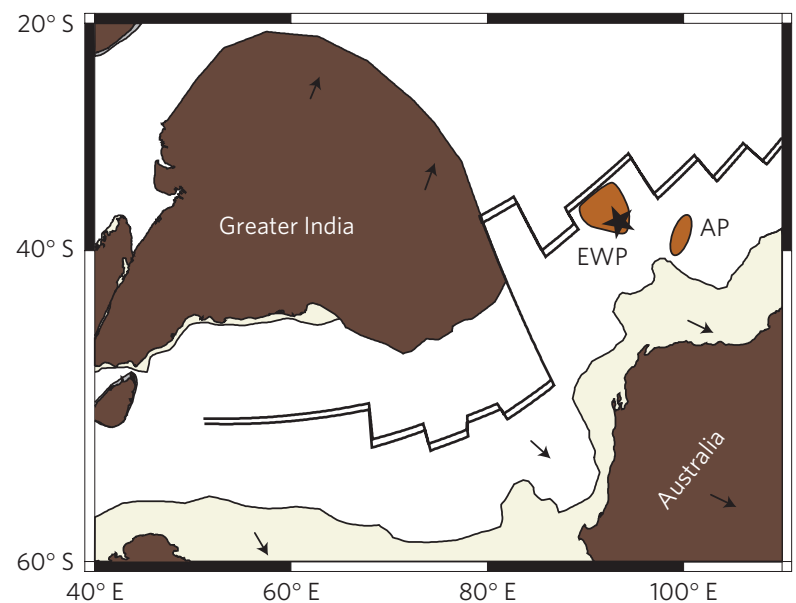

d $50 \mathrm{Myr}$

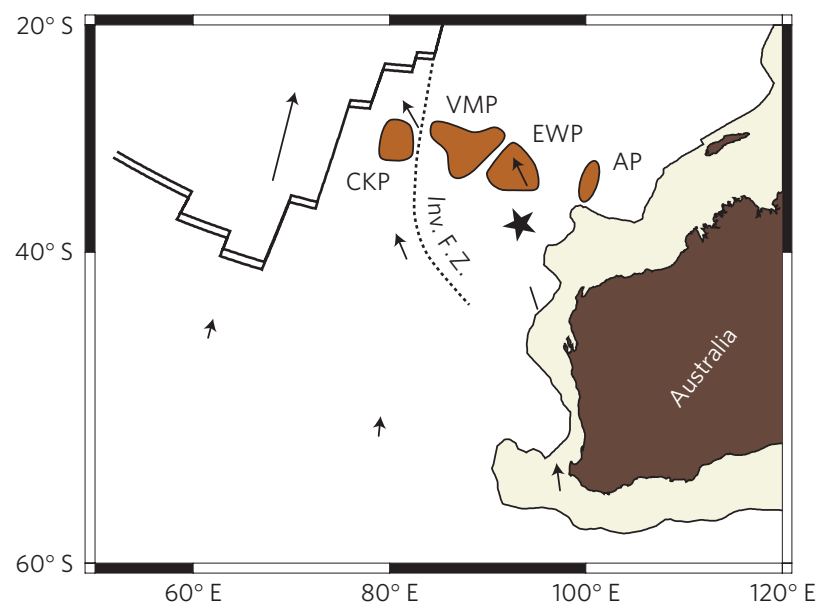

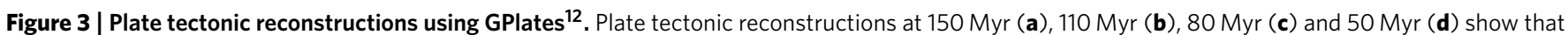
the CHRISP formed along and near the spreading centre, separating West Burma from Australia and Greater India, and that a fixed hotspot (star) located

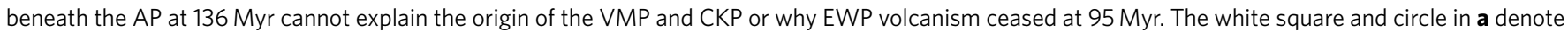
the location of the Millindinna Complex and NW Australian lamproites respectively. Investigator Fracture Zone (Inv. F.Z.) is also shown. See text and Supplementary Information S3 for more information.

increased from $\sim 70 \mathrm{~mm} \mathrm{yr}^{-1}$ at $136 \mathrm{Myr}$ to $120 \mathrm{~mm} \mathrm{yr}^{-1} \sim 85 \mathrm{Myr}$ ago and then decreased to $\sim 35 \mathrm{~mm} \mathrm{yr}^{-1}$ at $47 \mathrm{Myr}$ (Supplementary Information S3), at which time CHRISP volcanism ceased. The cessation of CHRISP volcanism could reflect a decrease in spreading rates, due to reduced upwelling rates and/or the passage of the MOR over the region where continental rifting and delamination took place. The westward decrease in age of volcanism reflects the westward migration of the MOR over the region where continental lithosphere was delaminated.

An important question concerns how much delaminated SCLM is needed to form the CHRISP. We estimate a maximum volume for the CHRISP volcanism of $\sim 100,000 \mathrm{~km}^{3}$. Assuming that average parental alkali basalt for the CHRISP was formed by at least $10 \%$ melting ${ }^{21}$, then we need a source volume of $\sim 1,000,000 \mathrm{~km}^{3}$ or a $\sim 1 \mathrm{~km}$ thick sheet the size of the CHRISP $(1,800 \times 600 \mathrm{~km})$ removed from the base of the lithosphere. If $90 \%$ of the melts formed intrusives, no doubt an overestimation, then this sheet would need to be $10 \mathrm{~km}$ thick. Alternatively, if Archaean SCLM with a vertical thickness of $200 \mathrm{~km}$ were convectively delaminated along $1,800 \mathrm{~km}$ of the rift system, then only $3-15 \mathrm{~km}$ on both sides of the rift would need to be removed. Even if ten times as much SCLM was delaminated as reached the CHRISP source, the dimensions of the delaminated SCLM are within those that can be estimated for the western US rift systems ${ }^{13-15}$.

The Aphanasy-Nikitin Rise and Seamount, which also have extreme EM1-type compositions (Fig. 2) and formed close to the Central Indian Ocean Ridge at $\geq 75 \mathrm{Myr}$ (ref. 8), could also have been generated through shallow recycling of delaminated Indian lithosphere. The Southwest Indian Ridge (SWIR) at $39^{\circ}-41^{\circ} \mathrm{E}$ has an extreme composition compared with the rest of the Indian ridge systems (Fig. 2) and could be an example of continental lithosphere at present upwelling beneath the ridge $^{22}$. The Eocene phase of volcanism on Christmas Island indicates that E-MORB-type material, possibly young recycled ocean crust ${ }^{23}$, upwelled and melted beneath $55 \mathrm{Myr}$ old crust and thus in an intraplate setting. The Pliocene volcanic rocks, which formed on $100 \mathrm{Myr}$ old ocean crust, provide compelling evidence that EM1-type components are still located in the shallow mantle beneath the Indian Ocean, well away from hotspot tracks or MORs. This very low volume volcanism took place when Christmas Island was uplifted, as it moved onto the flexural bend outboard of the Java Trench, and thus formed in a similar tectonic setting to the Petit Spot seamounts, which formed outboard of the Japan Trench ${ }^{24}$. Bending and uplift of 


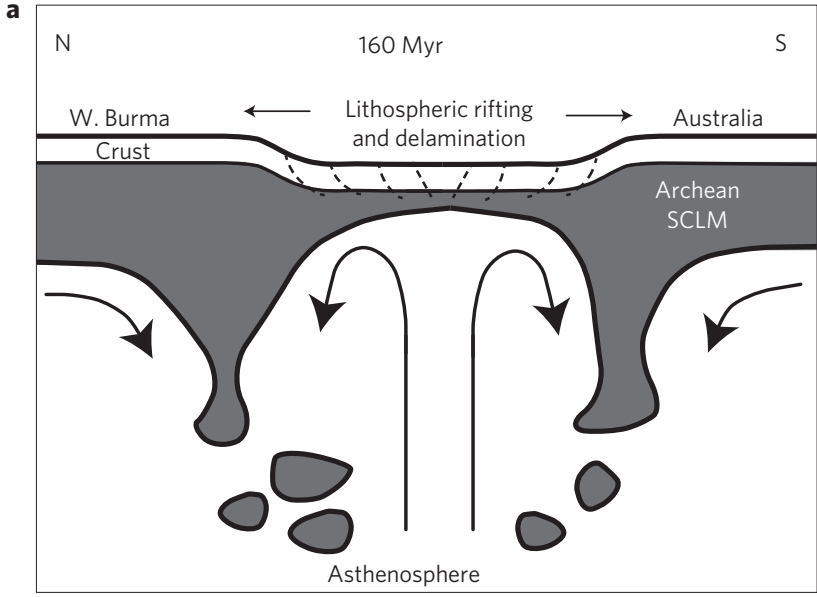

$40^{\circ} \mathrm{S}, 90^{\circ} \mathrm{E}$

$35^{\circ} \mathrm{S}, 90^{\circ} \mathrm{E}$

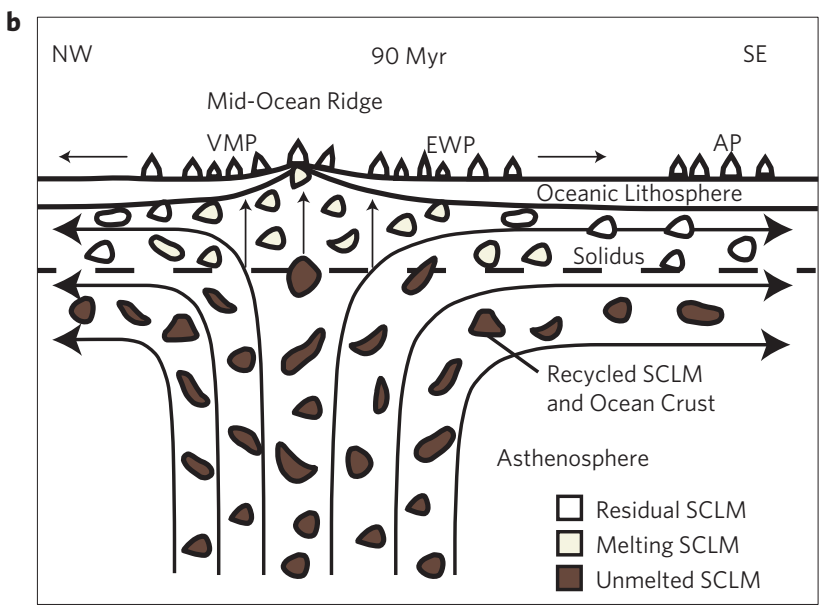

$40^{\circ} \mathrm{S}, 105^{\circ} \mathrm{E}$

$35^{\circ} \mathrm{S}, 80^{\circ} \mathrm{E}$

Figure 4 | Model explaining the origin of the CHRISP through shallow recycling of continental lithosphere. a, During rifting of West Burma from Australia and Greater India, subcontinental lithosphere (SCLM) was delaminated. b, Subsequently, strong passive upwelling beneath the fast spreading West Burma-Australia Ridge entrained delaminated SCLM and young subducted oceanic crust (solid blobs). Decompression melting of SCLM beneath the spreading centre formed the CHRISP (after ref. 20). SCLM and ocean crust that flow away from the ridge axis beneath the solidus (dashed line) can at a later stage rise above the solidus and melt to form intraplate volcanism, such as on Christmas Island.

the subducting plate could generate low-degree decompression melts, whereas extension and bend-faulting could facilitate the rise of these melts to the surface. The Petit Spot seamounts and the small, isolated Godzilla seamount in the North Atlantic $\left(38^{\circ} \mathrm{N}\right)$, which also cannot be related to a hotspot ${ }^{25}$, provide evidence for the presence of enriched material within the uppermost asthenospheric mantle globally.

In conclusion, shallow recycling of ancient metasomatized continental lithosphere and young ocean crust, both at MORs and beneath plates, could be an important mechanism for generating seamount and ocean island (preserved as guyots) volcanism. Although the origin of the enriched composition in Indian and South Atlantic MORB and intraplate volcanic rocks (DUPAL anomaly ${ }^{26}$ ) is controversial (see, for example, refs $25,27,28$ ), our results suggest that shallow recycling of continental lithosphere is likely to play an important role in ocean basins recently formed by continental breakup. Deep recycling of continental lithosphere through mantle plumes, however, is also likely to play an important role $22,29,30$. Older ocean basins, such as the Pacific, have undergone long-term processing of their upper mantle through MORs, thereby having largely exhausted any fertile continental lithospheric material from ancient continental breakup involved in forming the ocean basin.

Received 2 June 2011; accepted 26 October 2011; published online 27 November 2011

\section{References}

1. Morgan, W. J. in The Oceanic Lithosphere (ed. Emiliani, C.) 443-489 (Wiley, 1981).

2. Duncan, R. Age progressive volcanism in the New England seamounts and the opening of the Central Atlantic Ocean. J. Geophys. Res. 89, 9980-9990 (1984).

3. McDougall, I. Volcanic island chains and sea floor spreading. Nature Phys. Sci. 231, 141-144 (1971).

4. Wessel, P., Sandwell, D. T. \& Kim, S-S. The global seamount census. Oceanography 23, 24-33 (2010).

5. Heine, C., Müller, R. D. \& Gaina, C. in Continent-Ocean Interactions Within East Asian Marginal Seas 37-54 (AGU Geophysical Monograph Series, Vol. 124, (eds Clift, P., Wang, P., Kuhnt, W. \& Hayes, D.), American Geophysical Union, 2004).

6. Liu, C-S., Curray, J. R. \& McDonald, J. M. New constraints on the tectonic evolution of the eastern Indian Ocean. Earth Planet. Sci. Lett. 65, 331-342 (1983).

7. Mahoney, J. J., White, W. M., Upton, B. G. J., Neal, C. R. \& Scrutton, R. A. Beyond EM-1: Lavas from Afanasy-Nikitin Rise and the Crozet Archipelago, Indian Ocean. Geology 24, 615-618 (1996).

8. Borisova, A. Y., Belyatsky, B. V., Portnyagin, M. V. \& Sushchevskaya, N. M. Petrogenesis of Olivine-phyric basalts from the Aphanasey Nikitin Rise: Evidence for contamination by cratonic lower continental crust. J. Petrol. 42, 277-319 (2001).

9. Fraser, K. J., Hawkesworth, C. J., Erlank, A. J., Mitchell, R. H. \& Scott-Smith B. H. Sr, Nd and $\mathrm{Pb}$ isotope and minor element geochemistry of lamproites and kimberlites. Earth Planet. Sci. Lett. 76, 57-70 (1985).

10. Chakrabarti, R., Basu, A. R. \& Paul, D. K. Nd-Hf-Sr-Pb isotopes and trace element geochemistry of Proterozoic lamproites from southern India: Subducted komatiite in the source. Chem. Geol. 236, 291-302 (2007).

11. Korsch, M. J. \& Gulson, B. L. Nd and Pb isotopic studies of an Archaean layered mafic-ultramafic complex, Western Australia, and implications for mantle heterogeneity. Geochim. Cosmochim. Acta 50, 1-10 (1986).

12. Boyden, J. A. et al. in Geoinformatics: Cyberinfrastructure For The Solid Earth Sciences (eds Keller, G.R. \& Baru, C.) 95-114 (Cambridge Univ. Press, 2011).

13. Gao, W. et al. Upper mantle convection beneath the central Rio Grande rift imaged by $\mathrm{P}$ and S wave tomography. J. Geophys. Res. 109, B03305 (2004).

14. Crow, R. et al. Shrinking of the Colorado Plateau via lithospheric mantle erosion: Evidence from $\mathrm{Nd}$ and $\mathrm{Sr}$ isotopes and geochronology of Neogene basalts. Geology 39, 27-30 (2011).

15. van Wijk, J., van Hunen, J. \& Goes, S. Small-scale convection during continental rifting: Evidence from the Rio Grande rift. Geology 36, 575-578 (2008).

16. Griffin, W. L., O’Reilly, S. Y., Natapov, L. M. \& Ryan, C. G. The evolution of lithospheric mantle beneath the Kalahari Craton and its margins. Lithos 71, 215-241 (2003).

17. Schutt, D. L. \& Lesher, C. E. Compositional trends among Kaapvaal Craton garnet peridotite xenoliths and their effects on seismic velocity and density. Earth Planet. Sci. Lett. 300, 367-373 (2010).

18. Poudjom Djomani, Y. H., O’Reilly, S. Y., Griffin, W. L. \& Morgan, P. The density structure of subcontinental lithosphere through time. Earth Planet. Sci. Lett. 184, 605-621 (2001).

19. Korenaga, J. Mantle mixing and continental breakup magmatism. Earth Planet. Sci. Lett. 218, 463-473 (2004).

20. Korenaga, J. Firm mantle plumes and the nature of the core-mantle boundary region. Earth Planet. Sci. Lett. 232, 29-37 (2005).

21. Frey, F. A., Green, D. H. \& Roy, S. D. Integrated models of basalt petrogenesis: A study of quartz tholeiites to olivine melilitites from south eastern Australia utilizing geochemical and experimental petrological data. J. Petrol. 19, 463-513 (1978)

22. Mahoney, J., LeRoex, A. P., Peng, Z., Fisher, R. L. \& Natland, J. H. Southwestern limits of Indian Ocean ridge mantle and the origin of low ${ }^{206} \mathrm{~Pb} /{ }^{204} \mathrm{~Pb}$ Mid-Ocean Ridge basalt: Isotope systematics of the central southwest Indian Ridge (17\%-50 ${ }^{\circ}$ E). J. Geophys. Res. 97, 19771-19790 (1992).

23. Hanan, B. B. \& Graham, D. W. Lead and helium isotope evidence from oceanic basalts for a common deep source of mantle plumes. Science 272, 991-995 (1996).

24. Hirano, N. et al. Volcanism in response to plate flexure. Science 313, 1426-1428 (2006). 
25. Geldmacher, J., Hoernle, K., Klügel, A., van den Bogaard, P. \& Bindeman, I. Geochemistry of a new enriched mantle type locality in the northern hemisphere: Implications for the origin of the EM-I source. Earth Planet. Sci. Lett. 265, 167-182 (2008).

26. Hart, S. R. A large-scale isotope anomaly in the Southern Hemisphere mantle. Nature 309, 753-757 (1984).

27. Escrig, S., Capmas, F., Dupré, B. \& Allègre, C. J. Osmium isotopic constraints on the nature of the DUPAL anomaly from Indian mid-ocean-ridge basalts. Nature 431, 59-63 (2004).

28. Hanan, B. B., Blichert-Toft, J., Pyle, D. G. \& Christie, D. M. Contrasting origins of the upper mantle revealed by hafnium and lead isotopes from the Southeast Indian Ridge. Nature 432, 91-94 (2004).

29. Class, C. \& le Roex, A. South Atlantic DUPAL anomaly—Dynamic and compositional evidence against a recent shallow origin. Earth Planet. Sci. Lett. 305, 92-102 (2011).

30. Mahoney, J. J. et al. Tracing the Indian Ocean mantle domain through time: Isotopic results from old West Indian, East Tethyan, and South Pacific seafloor. J. Petrol. 39, 1285-1306 (1998).

31. Amante, C. \& Eakins, B. W. ETOPO1 1 Arc-Minute Global Relief Model: Procedures, Data Sources and Analysis NOAA Technical Memorandum NESDIS NGDC-24 (National Geophysical Data Center, 2009).

\section{Acknowledgements}

We thank the captain and crew of the RV Sonne for a successful cruise; J. Sticklus, S. Hauff and J. Fietzke for analytical support; T. Falloon for sharing an unpublished manuscript on Christmas Island with us; J. Geldmacher and U. Barckhausen for comments and C. Class and S. Gibson for constructive reviews; and the German Ministry of Education and Research (BMBF) for financial support of the SO199 CHRISP project.

\section{Author contributions}

K.H., F.H. and R.W. conceived the project; K.H. interpreted the data and wrote the paper with intellectual input from all co-authors except S.C.; K.H., R.W., F.H., A.D.G. and S.C. organized and carried out the SO199 cruise; P.v.d.B. generated the age data; F.H. and S.C. generated the isotope data; A.D.G. and R.D.M. generated the plate tectonic reconstructions.

\section{Additional information}

The authors declare no competing financial interests. Supplementary information accompanies this paper on www.nature.com/naturegeoscience. Reprints and permissions information is available online at http://www.nature.com/reprints. Correspondence and requests for materials should be addressed to K.H. 